\title{
Techniques adopted in teaching students organic chemistry course for several years
}

\author{
Wati Sukmawati \\ Universitas Muhammadiyah Prof. DR. HAMKA Jl. Delima No. II/IV, Klender, Jakarta, 13460, Indonesia \\ * Coressponding Author. E-mail: wati_sukmawati@uhamka.ac.id
}

Received: 14 December 2020; Revised: 25 December 2020; Accepted: 30 December 2020

\begin{abstract}
Abstrak: Organic chemistry is a compulsory course for both science and science education students. Therefore a proper course design is needed to ease the understanding of the concepts considered difficult in terms of learning activities, application of technology, and innovation in the curriculum structure. Various studies have been carried out to solve problems in organic chemistry courses, with the majority focused on concept mastery due to students' difficulty. Furthermore, their thinking skills need to be improved after graduating from the university in accordance with the $21^{\text {st }}$ century, which is associated with the application of technology and curriculum modification. The results showed that most studies in organic chemistry courses focused on improving students' concept, understanding, and thinking abilities. Therefore, little application of technology and curriculum modification is still needed in the innovation of organic chemistry courses, especially in applying technology. In conclusion, courses related to organic chemistry still need innovation, especially in the application of technology. This research can serve as a reference for developing organic chemistry learning in the future.
\end{abstract}

Keywords: curriculum, learning activity, organic chemistry course, technology.

How to Cite: Sukmawati, W. (2020). Techniques adopted in teaching students organic chemistry course for several years. Jurnal Inovasi Pendidikan IPA, 6(2), 247-256. doi:https://doi.org/10.21831/jipi.v6i2.38094

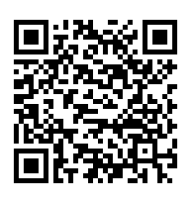

\section{INTRODUCTION}

Learning activities are the core of education in schools. Therefore it needs to be an essential concern for all education practitioners, teachers, stakeholders, and students. As class teachers, lecturers need to continue to find new teaching methods to improve the quality of courses related to organic chemistry. This, in turn, tends to improve the overall quality of student education. Several learning designs that were previously applied over the years, including the inverted classroom design (Tune et al., 2013), student-centered design (Gordon et al., 2013), modified curriculum with practice in real evidence (Finotto et al., 2013), problem-based learning design (Yanqi Zhang et al., 2015) collaborative learning (O’Neal et al., 2016) case learning design (Xiong, 2016) service-learning design (Najmr et al., 2018) reverses classroom design integrated with ICT and e-learning (Ahn, 2019) online learning design (Pei $\& \mathrm{Wu}, 2019$ ) and active learning design (Theobald et al., 2020).

The development of information technology (ICT) in the 21st century has become necessary in developing the quality of learning in schools, especially millennials, as learning subjects close to technology. The topic of focus in this research is organic chemistry, which science students widely study. Efforts related to improving this learning design are through class activities. However, the techniques used by the lecturers to teach students organic chemistry have not been determined. Therefore, this study aims to determine the historical application of teaching and learning activities in organic chemistry.

Based on the objectives of this study, it is expected to be able to provide quality information on the process of learning activities in organic chemistry courses so that students can answer the challenges of learning in the 21 st century and become a reference for conveying the organic chemistry learning process that students will accept. This review is focused on articles on learning organic chemistry.

\section{METHOD}

Researchers researched by selecting several journals taken through Google Scholar with the types of articles indexed or not indexed by Scopus. The search activity carried out with the Google Scholar software was focused on combining the selected keywords, including the keywords learning organic 
chemistry and teaching organic chemistry. The search was carried out in July 2020. Based on the search, it was found that there were more than 100 articles published in the years 2012-2020. Based on the articles found, there are only about 65 articles that match the research focus. Researchers only conduct research based on the results of the articles' analysis and do not take from books or others.

After the articles by the focus of the study were grouped as many as 65 article documents, the next step was to analyze the titles and abstracts adjusted to the study's scope. Next, the data extraction of the research results from the analyzed articles was carried out, especially on the focus of the application of organic chemistry learning that has been carried out in various countries.

The topic which is the focus of this research is organic chemistry. The 65 articles selected had fulfilled the requirements with topics that were by the focus of the research. After the article has been successfully analyzed from title to content, the next stage is grouping the articles. The articles' grouping is divided into three groups, namely articles that discuss how universities compile the organic chemistry curriculum, organic chemistry learning modified by lecturers, and how technology is applied in teaching organic chemistry courses.

\section{RESULT AND DISCUSSION}

Figure 1 is the process of teaching organic chemistry by lecturers from 2012 to 2020 .
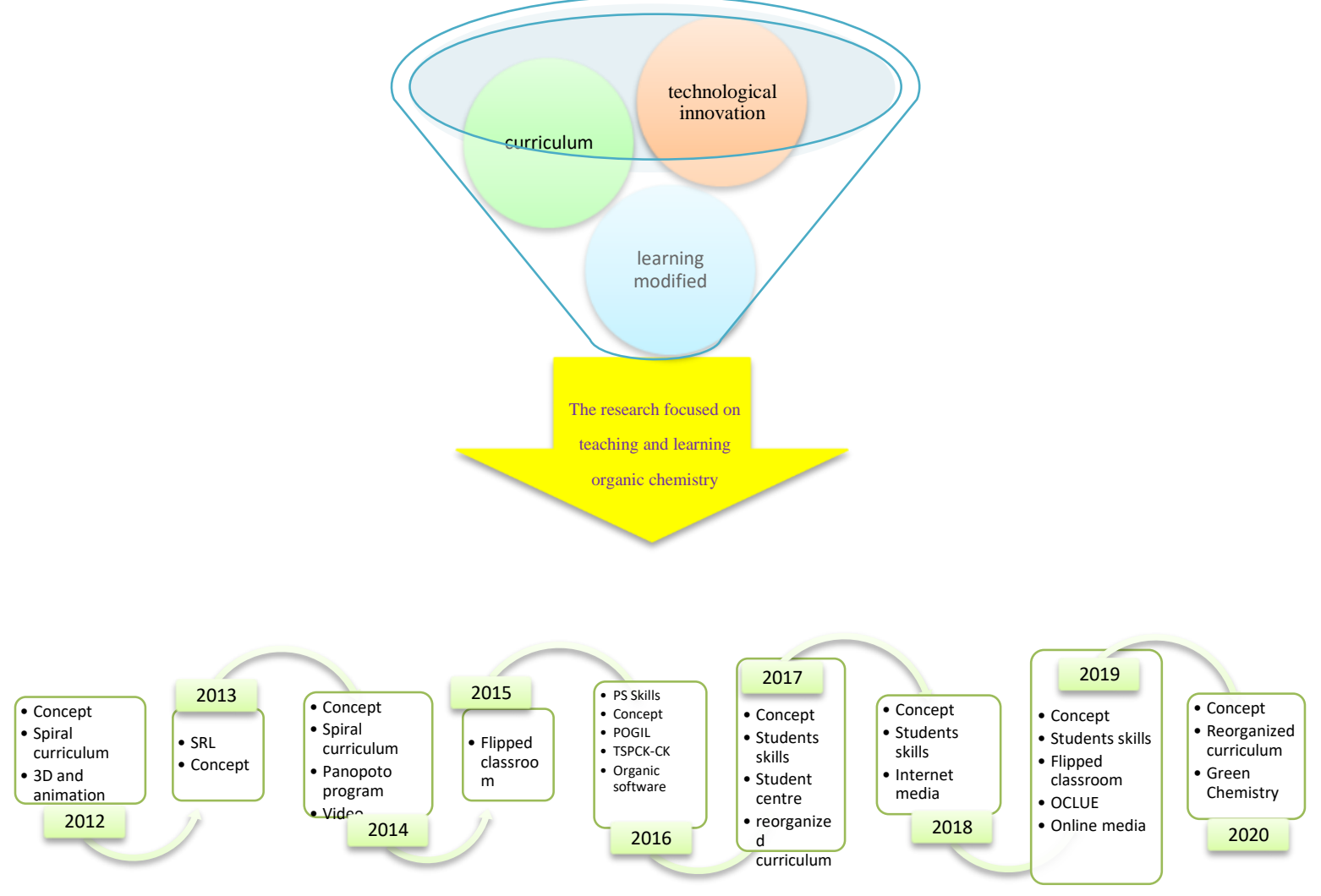

Figure 1. Trend of Organic Chemistry Course for Several Years

(2012) The act of teaching organic chemistry was focused on identifying the difficult concept and developing alternative methods for students' understanding (McClary \& Bretz, 2012). Grove \& Lowery Bretz (2012), implemented spiral curriculum, Stull et al. (2012) used the concrete models to describe molecule structure, while Talib et al. (2012) used Simple Explicit Animation (SEA).

(2013) During this year, teaching organic chemistry focused on improving student's behavior in seeking and correlating it with prior chemistry aptitude (Horowitz et al., 2013). Lopez et al. (2013) applied the SRL (Self-Regulated Learning) method, while Raker et al. (2013) assessed students to determine their cognitive knowledge of organic chemistry.

(2014) Lecturers tried to students on ways to master the connection between the theory obtained in class and the real world (Bhattacharyya \& Bodner, 2014). The difficult concept such as organic nomenclature, bonding, mechanism, reagents or products, and synthesis were analyzed (Austin et al., 
2015). Furthermore, Flynn (2014) introduced the act of mastering the concepts and use of high order thinking, especially in problem-solving skills, in order to build students' synthesis skills. Learning organic chemistry using technology was also achieved by the screen-capture method using a program named Panopto, which was developed by Dangelo (2014). Christiansen (2014) also invented the inverted teaching (IT), whereby homework was conducted together in the class, and the transfer concept carried out by students at home by watching related videos. The last, organic chemistry learning focused on reorganizing the used Spiral curriculum, with organic content separated in the cycle, and not consecutive topics. The cycle started with an introduction to the fundamentals of organic chemistry, with the subsequent ones forcing the learner to recall and relearn the topics previously learned $\left(\mathrm{O}^{\prime}\right.$ Dwyer \& Childs, 2014)

(2015) Organic chemistry was taught using the flipped classroom, which was guided by the lecturer for engaging activities and problem-solving, therefore the content learning was carried out at home (Fautch, 2015).

(2016) This year, organic chemistry was taught using the problem-solving scaffold (Bodé \& Flynn, 2016; Sloop et al., 2016) and analogy approaches, especially in the abstract matter (Samara, 2016). Furthermore, the process-oriented guided inquiry learning (POGIL) (Carneiro et al., 2016), Topic-Specific Pedagogy Content Knowledge (TSPCK) and Content Knowledge (CK) (Davidowitz \& Potgieter, 2016) methods were implemented, with various chemistry software such as Chem Office, Hyperchem, and Gaussian 03, used to improve student spatial thinking skills (Wang, 2016).

(2017) The process of learning organic chemistry focused on building a framework for improving student mechanistic reasoning (Caspari et al., 2018) while exploring the intersections of teachers' and students' perceptions of the difficult concepts (O'Dwyer \& Childs, 2017). Canelas et al. (2017) used cooperative learning, including inquiry, analysis, critical thinking, and the basic principles of scientific reasoning within the context of organic chemistry to improve problem-solving skills and scientific ways of thinking (Stowe \& Cooper, 2017). Furthermore, the application of student-centered learning with active learning model such as collaborative learning, cooperative learning, and problem-based learning developed by Crimmins \& Midkiff (2017), as well as the application of argumentation activities to minimize their difficulties in learning the topic required memorization (Pabuccu \& Erduran, 2017), and use of the flipped classroom to build active learning (Cormier \& Voisard, 2018). Organic chemistry was also taught with the modified curriculum in the language, such as specific reaction involving electronpushing (Galloway et al., 2017) and by reforming the curriculum, which combined the theory and practice (Yunshen Zhang, 2017)

(2018) The learning started with analyzing the difficult concepts of organic chemistry, and its general application as basic matter (Ealy, 2018), by applying the model of PBL (Problem Based Learning) (Al-Salihi \& Alobaidi, 2018), and increasing the self-confidence of students (Angelini \& Gasbarri, 2018). The act of learning organic chemistry also used online technology computing, designed as automatic vehicles with systematic (Fellicious, 2018). Furthermore, an animation media such as interactive computer visualization (ICV) which used the Roger Frost organic animation package (NgoziOlehi et al., 2018), and technology internet Web 2.0, for courses involving diverse techniques, services and tools that enable participants to actively collaborate with the creation of content, generating of knowledge and sharing of information via online media (Romero et al., 2018).

(2019) The lecturers taught critical and system high order thinking skills in learning organic chemistry (Timofte \& Popuș, 2019), with the application of the flipped classroom (Rocabado et al., 2019 and Broman \& Johnels, 2019) and Bridge activity which is transits the activity from pre-class preparation to in-class learning (Stewart \& Dake, 2019). Organic chemistry was also taught using a card game designed to help students understand the substitution and elimination reactions of alkyl halides named CHEMCompete (Camarca et al., 2019). Technology, through the use of artificial intelligence, was also used to predict organic compound products without laboratory practice (Peiretti \& Brunel, 2018). The last learning process modified the curriculum by implementing OCLUE (Organic Chemistry, Life, the Universe, and Everything), which involves organic content accompanied by the use of realworld applications (Cooper et al., 2019).

(2020) In 2020, the act of learning organic chemistry focused on causal mechanistic arrows in substitution reaction (Crandell et al., 2020), the application of chemical structure teaching (CST) (Zheng et al., 2020), use of card game especially in learning functional group (Bell et al., 2020), and application of Posner's approach by implementing the design-based research technique (Kaanklao \& 


\section{Jurnal Inovasi Pendidikan IPA, 6 (2), 2020 - 250}

Wati Sukmawati

Suwathanpornkul, 2020). Furthermore, it focused on the terminal object (TOs), and the development of specific students' capabilities (Betancourt-Pérez et al., 2020).

Organic chemistry learned by reorganized the curriculum, It focused on the interrelationships of organic reaction mechanisms, which emphasizes the core concepts, such as the interconnectedness of topics, logical hierarchy of topics, and promoting reasoning through analogy and first principles. Lipton (2020) implemented 1-2-1 curriculum, with the sequence of learning as follows: General Chemistry I, Organic Chemistry I and II, and General Chemistry II. It is different from the past, where Organic Chemistry was taught after General Chemistry I and II (Provencher et al., 2020). The curriculum was revised by incorporating the theme of green chemistry (Holme et al., 2020).

This research is divided into three parts, which are focused on the organic modified curriculum, chemistry concept, and applied technology. The curriculum is a set of learning needs that involves goals, subject matter, teaching plan, documents, and experiences (Alsubaie, 2016; Su, 2012). It is part of the education system that never separated from learning activity in an organic chemistry course. Several experiments applied the modified curriculum in an organic chemistry course for years with the knowledge that the curriculum is focused on education research. Therefore, several studies focused on the application of modified curriculum in teaching and learning organic chemistry (Childs \& O' Dwyer, 2014; Cooper et al., 2019; Galloway et al., 2017; Grove \& Lowery Bretz, 2012; Holme et al., 2020; ipton, 2020; Provencher et al., 2020; Yunshen Zhang, 2017)

Courses related to organic chemistry are applied in the spiral curriculum, which is reviewed repeatedly in a course while including the required themes and topics in every meeting (Harden \& Stamper, 1999). The spiral curriculum is focused on reorganizing the curriculum, separated by organic content and not consecutive topics. The cycle started with an introduction to the fundamentals of organic chemistry, with subsequent cycles used to mandate the learner to recall and relearn the topics learned (O' Dwyer \& Childs, 2014). The spiral curriculum was implemented with a combination of meaningful learning and application of the Ausubel assimilation theory (Grove \& Lowery Bretz, 2012). The 1-2-1 curriculum was designed to ensure the successful implementation of organic chemistry learning, in learning of General Chemistry I, Organic Chemistry I and II, and General Chemistry II. This was different from the past, where Organic Chemistry was taught after General Chemistry I and II (Provencher et al., 2020)

The other reorganized curriculum in organic chemistry is associated with language, such as specific reaction which involves electron-pushing (Galloway et al., 2017). The modified curriculum was carried out by focusing on the interrelationships of organic reaction, mechanisms, and emphasis on the core concepts. These include the interconnectedness of topics, promoting analogical reasoning, first principles, and the logical hierarchy of topics (Lipton, 2020). This was followed by modifying the curriculum applied in the real world of the organic theory, by combining the theory and practice (Yunshen Zhang, 2017), and implementing OCLUE (Organic Chemistry, Life, the Universe, and Everything). It also involves the organic content, accompanied by the real-world application (Cooper et al., 2019). The last is the process of modifying the organic chemistry curriculum by incorporating the theme of green chemistry in every organic matter (Holme et al., 2020).

The learning activity is the core of an educational process, however, teachers find it difficult to improve the course quality with the application of new strategies in solving the problems of student difficulties in mastering concepts or improving their way of thinking (Austin et al., 2015; Ealy, 2018; McClary \& Bretz, 2012; O’Dwyer \& Childs, 2017; Raker et al., 2013). O’Dwyer and Childs (2017) reported that learning modified in organic chemistry started by exploring teachers' and students' perceptions of the difficulty associated with teaching and learning the course. It also focused on alternative conceptions from students (McClary \& Bretz, 2012). The lecturers interrogate students' abilities in content complexity. They are also assessed to determine their cognitive skill in organic chemistry in accordance with their organic nomenclature, bonding, mechanism, reagents or products, synthesis, etc (Raker et al., 2013). Austin et al. (2015), applied general chemistry as the basic matter, with the terminal objects (TOs) used to describe students' abilities (Ealy, 2018; Betancourt-Pérez et al., 2020).

Organic chemistry is a difficult course, comprises of causal mechanistic arrows used to substitute the reaction or nucleophilic attack, which is the simplest type of organic reaction (Crandell et al., 2020). Moreover, high order thinking is needed in solving the problem reaction mechanisms and chemical principles (Flynn, 2014). It is also associated with the topic of organic chemistry that requires 


\section{Jurnal Inovasi Pendidikan IPA, 6 (2), 2020 - 251}

Wati Sukmawati

memorization, which is solved with argumentation activities and used to minimize student difficulties (Pabuccu \& Erduran, 2017). Kaanklao and Suwathanpornkul (2020) stated that the difficult concept associated with learning organic chemistry makes students have misconceptions on the subject of organic chemistry, with Posner's approach.

The other problem associated with learning organic chemistry is the abstract matter, which can be solved using analogy approaches (Samara, 2016) with students' guided by lecturers to master the connection and determine the differences between the class and real-world theories. Bhattacharyya \& Bodner (2014) stated that students are guided to practice organic theory in the laboratory, with the frequent use of the scaffolding information. Students' self-confidence increases by solving the problems of organic chemistry from easier to more difficult (Angelini \& Gasbarri, 2018).

The lecturers also tried to improve their course quality using the Topic-Specific Pedagogy Content Knowledge (TSPCK), Content Knowledge (CK) (Davidowitz \& Potgieter, 2016), and process-oriented guided inquiry learning (POGIL) (Carneiro et al., 2016). Therefore, they provided an alternative method for students in a group activity to enjoy learning organic chemistry by using the card game and puzzles (Bell et al., 2020).

Students' mastery of concepts, such as learning organic chemistry, is also needed to improve their synthesis skills and solved the problem of organic compound synthesis (Flynn, 2014). Furthermore, the problem-solving scaffold approach developed by (Bodé \& Flynn, 2016; Sloop et al., 2016), as well as the building framework for improving student mechanistic reasoning in organic chemistry (Caspari et al., 2018), was used to improve their problem solving skills and problem-solving of thinking (Stowe \& Cooper, 2017). Timofte and Popuș (2019) stated that critical and systems thinking skills were used to seek and correlate students' knowledge of chemistry (Horowitz et al., 2013),

The majority of lecturers tried to modify learning activity in their organic chemistry course by applying teaching models, such as SRL (Self-Regulated Learning). The metacognitive strategies or selfmonitoring and thinking management of students were also used to solve problems related to organic chemistry (Lopez et al., 2013). Canelas et al. (2017) used cooperative learning, including inquiry, analysis, critical thinking, and the basic principles of scientific reasoning, with collaborative, cooperative, and problem-based learning (Crimmins \& Midkiff, 2017). PBL (Problem Based Learning) (Al-Salihi \& Alobaidi, 2018), and the creative method with chemical structure teaching (CST) method, were used to build critical and logical thinking abilities of students. The learning started from the compound structure, followed by students analyzing the properties, which was finally verified by the textbook (Zheng et al., 2020).

The popular model applied several years ago in organic chemistry is the flipped classroom, which is guided by the lecturer for engaging activities and problem-solving (Fautch, 2015). The content learning carried out in the home is applied to build active learning (Cormier \& Voisard, 2018; Rocabado et al., 2019) with Bridge activity acting as a transition from pre-class preparation to in-class learning (Stewart \& Dake, 2019) to enable students to be more active and focus (Broman \& Johnels, 2019). Currently, technology is not only used in industry, rather it is also utilized to evaluate students' activities at home. In addition, technology is also used by lecturers to teach students organic chemistry based on the use of concrete models to directly describe the molecule structure, represented with 3D (Stull et al., 2012) and learning reaction mechanism concepts used in the Simple Explicit Animation (SEA) (Talib et al., 2012). The computer technology also provides animation media such as interactive computer visualization (ICV), Roger Frost organic animation package (Ngozi-Olehi et al., 2018) and the game media by using a card game designed to help students understand the substitution and elimination reactions of alkyl halides, named CHEMCompete (Camarca et al., 2019).

Other techniques used in learning organic chemistry is software by the screen-capture with program Panopto developed by Dangelo (2014), Chem Office, Hyperchem, and Gaussian 03 (Wang, 2016). Blended learning was also applied in learning organic chemistry by designing inverted teaching (IT), which enabled students to proceed with the learning concept at home by watching videos (Christiansen, 2014). The internet enables students to take advantage of online media with computing technology, designed as automatic vehicles on the organic concept, and make it systematic (Fellicious, 2018). Furthermore, it is used to predict organic compound products without prior practice in the laboratory, such as the use of artificial intelligence (Peiretti \& Brunel, 2018). 


\section{Jurnal Inovasi Pendidikan IPA, 6 (2), 2020 - 252}

Wati Sukmawati

Learning organic used technology internet Web 2.0, with diverse techniques, services, and tools that enable participants to carry out active collaboration in the creation of content, generation of knowledge and sharing of information via online media (Romero et al., 2018).

\section{CONCLUSION}

Several techniques have been applied to solve the problems associated with teaching and learning organic chemistry courses. The results showed that most studies in organic chemistry courses focused on improving students' concept, understanding, and thinking abilities. Therefore, little application of technology and curriculum modification is still needed in the innovation of organic chemistry courses, especially in applying technology.

\section{REFERENCE}

Ahn, K. (2019). A teaching model for undergraduate students. International Journal of Higher Education, 8(3), 29. https://doi.org/10.5430/ijhe.v8n3p29

Al-Salihi, F. G., \& Alobaidi, A. H. A. (2018). Problem based learning (PBL) in organic chemistry. International Journal of Medical Sciences, 1(2), 64-70.

Alsubaie, M. A. (2016). Curriculum development: Teacher involvement in curriculum development. Journal of Education and Practice, 7(9), 106-107.

Angelini, G., \& Gasbarri, C. (2018). Learning organic chemistry day by day: The best choice of the best pharmacy students. Currents in Pharmacy Teaching and Learning, 10(6), 795-802. https://doi.org/10.1016/j.cptl.2018.03.003

Austin, A. C., Ben-Daat, H., Zhu, M., Atkinson, R., Barrows, N., \& Gould, I. R. (2015). Measuring student performance in general organic chemistry. Chemistry Education Research and Practice, 16(1), 168-178. https://doi.org/10.1039/c4rp00208c

Bell, P. T., Martinez-Ortega, B. A., \& Birkenfeld, A. (2020). Organic chemistry i cassino: A card game for learning functional group transformations for first-semester students. Journal of Chemical Education, 97(6), 1625-1628. https://doi.org/10.1021/acs.jchemed.9b00995

Betancourt-Pérez, R., Rodríguez, J., \& Muñoz-Hernández, L. (2020). Homing in on the capabilities that are most predictive of student success in the first semester of organic chemistry. Journal of Chemical Education, 97(3), 635-642. https://doi.org/10.1021/acs.jchemed.9b00568

Bhattacharyya, G., \& Bodner, G. M. (2014). Culturing reality: How organic chemistry graduate students develop into practitioners. Journal of Research in Science Teaching, 51(6), 694-713. https://doi.org/10.1002/tea.21157

Bodé, N. E., \& Flynn, A. B. (2016). Strategies of successful synthesis solutions: mapping, mechanisms, and more. Journal of Chemical Education, 93(4), 593-604. https://doi.org/10.1021/acs.jchemed.5b00900

Broman, K., \& Johnels, D. (2019). Flipping the class - University chemistry students' experiences from a new teaching and learning approach. Chemistry Teacher International, 1(1), 1-8. https://doi.org/10.1515/cti-2018-0004

Camarca, M., Heuett, W., \& Jaber, D. (2019). CHEMCompete-II : An organic chemistry card game to differentiate between substitution and elimination reactions of alcohols. Journal of Chemical Education, 96(11), 2535-2539. https://doi.org/10.1021/acs.jchemed.9b00486

Canelas, D. A., Hill, J. L., \& Novicki, A. (2017). Cooperative learning in organic chemistry increases student assessment of learning gains in key transferable skills. Chemistry Education Research and Practice, 18(3), 441-456. https://doi.org/10.1039/C7RP00014F

Carneiro, G., Parulekar, T., Shridhar, G., \& Ladage, S. (2016). Experimenting with the teaching of organic chemistry - the process-oriented guided inquiry learning way. Current Science, 111(7), 1152-1155. https://doi.org/10.18520/cs/v111/i7/1152-1155

Caspari, I., Weinrich, M. L., Sevian, H., \& Graulich, N. (2018). This mechanistic step is "productive": organic chemistry students' backward-oriented reasoning. Chemistry Education Research and Practice, 19(1), 42-59. https://doi.org/10.1039/c7rp00124j 
Christiansen, M. A. (2014). Inverted teaching: Applying a new pedagogy to a university organic chemistry class. Journal of Chemical Education, 91(11), 1845-1850.

https://doi.org/10.1021/ed400530z

Cooper, M. M., Stowe, R. L., Crandell, O. M., \& Klymkowsky, M. W. (2019). Organic chemistry, life, the universe and everything (OCLUE): A transformed organic chemistry curriculum. Journal of Chemical Education, 96(9), 1858-1872. https://doi.org/10.1021/acs.jchemed.9b00401

Cormier, C., \& Voisard, B. (2018). Flipped classroom in organic chemistry has significant effect on students' grades. Frontiers in ICT, 4(JAN), 1-15. https://doi.org/10.3389/fict.2017.00030

Crandell, O. M., Lockhart, M. A., \& Cooper, M. M. (2020). Arrows on the page are not a good gauge: evidence for the importance of causal mechanistic explanations about nucleophilic substitution in organic chemistry. Journal of Chemical Education, 97(2), 313-327. https://doi.org/10.1021/acs.jchemed.9b00815

Crimmins, M. T., \& Midkiff, B. (2017). High structure active learning pedagogy for the teaching of organic chemistry: assessing the impact on academic outcomes. Journal of Chemical Education, 94(4), 429-438. https://doi.org/10.1021/acs.jchemed.6b00663

Dangelo, J. G. (2014). Use of screen capture to produce media for organic chemistry. Journal of Chemical Education, 91(5), 678-683. https://doi.org/10.1021/ed300649u

Davidowitz, B., \& Potgieter, M. (2016). Use of the Rasch measurement model to explore the relationship between content knowledge and topic-specific pedagogical content knowledge for organic chemistry. International Journal of Science Education, 38(9), 1483-1503. https://doi.org/10.1080/09500693.2016.1196843

Ealy, J. (2018). Analysis of students' missed organic chemistry quiz questions that stress the importance of prior general chemistry knowledge. Education Sciences, 8(2), 1-13. https://doi.org/10.3390/educsci8020042

Fautch, J. M. (2015). The flipped classroom for teaching organic chemistry in small classes: Is it effective? Chemistry Education Research and Practice, 16(1), 179-186. https://doi.org/10.1039/c4rp00230j

Fellicious, C. (2018). Transfer learning and organic computing for autonomous vehicles. https://arxiv.org/abs/1808.05443

Finotto, S., Carpanoni, M., Turroni, E. C., Camellini, R., \& Mecugni, D. (2013). Teaching evidencebased practice: Developing a curriculum model to foster evidence-based practice in undergraduate student nurses. Nurse Education in Practice, 13(5), 459-465. https://doi.org/10.1016/j.nepr.2013.03.021

Flynn, A. B. (2014). How do students work through organic synthesis learning activities? Chemistry Education Research and Practice, 15(4), 747-762. https://doi.org/10.1039/c4rp00143e

Galloway, K. R., Stoyanovich, C., \& Flynn, A. B. (2017). Students' interpretations of mechanistic language in organic chemistry before learning reactions. Chemistry Education Research and Practice, 18(2), 353-374. https://doi.org/10.1039/c6rp00231e

Gordon, J., Henry, P., \& Dempster, M. (2013). Undergraduate teaching assistants: a learner-centered model for enhancing student engagement in the first-year experience. International Journal of Teaching and Learning in Higher Education, 25(1), 103-109.

Grove, N. P., \& Lowery Bretz, S. (2012). A continuum of learning: From rote memorization to meaningful learning in organic chemistry. Chemistry Education Research and Practice, 13(3), 201-208. https://doi.org/10.1039/c1rp90069b

Harden, R. M., \& Stamper, N. (1999). What is a spiral curriculum? Medical Teacher, 21(2), 141-143. https://doi.org/10.1080/01421599979752

Holme, T. A., MacKellar, J., Constable, D. J. C., Michels, O. R., Trate, J. M., Raker, J. R., \& Murphy, K. L. (2020). Adapting the anchoring concepts content map (ACCM) of ACS exams by incorporating a theme: merging green chemistry and organic chemistry. Journal of Chemical Education, 97(2), 374-382. https://doi.org/10.1021/acs.jchemed.9b00564

Horowitz, G., Rabin, L. a, \& Brodale, D. L. (2013). Improving student performance in organic 


\section{Jurnal Inovasi Pendidikan IPA, 6 (2), 2020 - 254}

Wati Sukmawati

chemistry : Help seeking behaviors and prior chemistry aptitude. Journal of the Scholarship of Teaching and Learning, 13(3), 120-133.

Kaanklao, N., \& Suwathanpornkul, I. (2020). Development of the learning management process to enhance the chemistry learning achievement and conceptual comprehension on organic chemistry using the posner's approach with design-based research. Kasetsart Journal of Social Sciences, 41(2), 282-288. https://doi.org/10.1016/j.kjss.2018.07.016

Lipton, M. A. (2020). Reorganization of the organic chemistry curriculum to improve student outcomes. Journal of Chemical Education, 97(4), 960-964. https://doi.org/10.1021/acs.jchemed.9b00606

Lopez, E. J., Nandagopal, K., Shavelson, R. J., Szu, E., \& Penn, J. (2013). Self-regulated learning study strategies and academic performance in undergraduate organic chemistry: An investigation examining ethnically diverse students. Journal of Research in Science Teaching, 50(6), 660-676. https://doi.org/10.1002/tea.21095

McClary, L. M., \& Bretz, S. L. (2012). Development and assessment of a diagnostic tool to identify organic chemistry students' alternative conceptions related to acid strength. International Journal of Science Education, 34(15), 2317-2341. https://doi.org/10.1080/09500693.2012.684433

Najmr, S., Chae, J., Greenberg, M. L., Bowman, C., Harkavy, I., \& Maeyer, J. R. (2018). A servicelearning chemistry course as a model to improve undergraduate scientific communication skills. Journal of Chemical Education, 95(4), 528-534. https://doi.org/10.1021/acs.jchemed.7b00679

Ngozi-Olehi, L. C., Duru, C. E., Uchegbu, R. I., \& Amanze, K. O. (2018). Improving interest and performance in organic chemistry pedagogy by incooperating animations. American Journal of Educational Research, 6(3), 277-280. https://doi.org/10.12691/education-6-3-15

O’ Dwyer, A., \& Childs, P. (2014). Organic chemistry in action! developing an intervention program for introductory organic chemistry to improve learners' understanding, interest, and attitudes. Journal of Chemical Education, 91(7), 987-993. https://doi.org/10.1021/ed400538p

O'Dwyer, A., \& Childs, P. E. (2017). Who says organic chemistry is difficult? Exploring perspectives and perceptions. Eurasia Journal of Mathematics, Science and Technology Education, 13(7), 3599-3620. https://doi.org/10.12973/eurasia.2017.00748a

O’Neal, P. V., McClellan, L. C., \& Jarosinski, J. M. (2016). A new model in teaching undergraduate research: A collaborative approach and learning cooperatives. Nurse Education in Practice, 18, 80-84. https://doi.org/10.1016/j.nepr.2016.03.008

Pabuccu, A., \& Erduran, S. (2017). Beyond rote learning in organic chemistry: the infusion and impact of argumentation in tertiary education. International Journal of Science Education, 39(9), 11541172. https://doi.org/10.1080/09500693.2017.1319988

Pei, L., \& Wu, H. (2019). Does online learning work better than offline learning in undergraduate medical education? A systematic review and meta-analysis. Medical Education Online, 24(1), 1666538. https://doi.org/10.1080/10872981.2019.1666538

Peiretti, F., \& Brunel, J. M. (2018). Artificial intelligence: The future for organic chemistry? ACS Omega, 3(10), 13263-13266. https://doi.org/10.1021/acsomega.8b01773

Provencher, B. A., Franco, J., Fernandez, A. L., Theberge, S., \& Zwickau, B. (2020). Implementation of a 1-2-1 curriculum and its effect on organic chemistry I. Journal of Chemical Education, 97(5), 1303-1309. https://doi.org/10.1021/acs.jchemed.9b00900

Raker, J. R., Trate, J. M., Holme, T. A., \& Murphy, K. (2013). Adaptation of an instrument for measuring the cognitive complexity of organic chemistry exam items. Journal of Chemical Education, 90(10), 1290-1295. https://doi.org/10.1021/ed400373c

Rocabado, G. A., Kilpatrick, N. A., Mooring, S. R., \& Lewis, J. E. (2019). Can we compare attitude scores among diverse populations? an exploration of measurement invariance testing to support valid comparisons between black female students and their peers in an organic chemistry course. Journal of Chemical Education, 96(11), 2371-2382.

https://doi.org/10.1021/acs.jchemed.9b00516 


\section{Jurnal Inovasi Pendidikan IPA, 6 (2), 2020 - 255}

Wati Sukmawati

Romero, R. M., Vidal Espinoza, L. O., \& Ramírez Hernández, D. (2018). Organic chemistry basic concepts teaching in students of large groups at Higher Education and Web 2.0 tools. Actualidades Investigativas En Educación, 19(1), 31. https://doi.org/10.15517/aie.v19i1.35589

Samara, N. A. H. (2016). Effectiveness of analogy instructional strategy on undergraduate student's acquisition of organic chemistry concepts in Mutah University, Jordan. Journal of Education and Practice, 7(8), 70-74.

Sloop, J., Tsoi, M., \& Coppock, P. (2016). Benefits of using a problem-solving scaffold for teaching and learning synthesis in undergraduate organic chemistry I. International Journal for the Scholarship of Teaching and Learning, 10(1). https://doi.org/10.20429/ijsotl.2016.100108

Stewart, J. J., \& Dake, G. R. (2019). Activating students' prior knowledge using a bridge activity as an initial interactive discussion in a flipped organic chemistry course. Journal of Chemical Education, 96(11), 2426-2431. https://doi.org/10.1021/acs.jchemed.9b00370

Stowe, R. L., \& Cooper, M. M. (2017). Practicing what we preach: assessing "critical thinking" in organic chemistry. Journal of Chemical Education, 94(12), 1852-1859. https://doi.org/10.1021/acs.jchemed.7b00335

Stull, A. T., Hegarty, M., Dixon, B., \& Stieff, M. (2012). Representational translation with concrete models in organic chemistry. Cognition and Instruction, 30(4), 404-434. https://doi.org/10.1080/07370008.2012.719956

$\mathrm{Su}, \mathrm{S.-W}$. (2012). The various concepts of curriculum and the factors involved in curricula-making. Journal of Language Teaching and Research, 3(1), 153-158. https://doi.org/10.4304/jltr.3.1.153-158

Talib, O., Nawawi, M., Ali, W. Z. W., \& Mahmud, R. (2012). Simple explicit animation (SEA) approach in teaching organic chemistry. Procedia - Social and Behavioral Sciences, 69(Iceepsy), 227-232. https://doi.org/10.1016/j.sbspro.2012.11.403

Theobald, E. J., Hill, M. J., Tran, E., Agrawal, S., Arroyo, E. N., Behling, S., Chambwe, N., Cintrón, D. L., Cooper, J. D., Dunster, G., Grummer, J. A., Hennessey, K., Hsiao, J., Iranon, N., Jones, L., Jordt, H., Keller, M., Lacey, M. E., Littlefield, C. E., ... Freeman, S. (2020). Active learning narrows achievement gaps for underrepresented students in undergraduate science, technology, engineering, and math. Proceedings of the National Academy of Sciences, 117(12), 6476-6483. https://doi.org/10.1073/pnas.1916903117

Timofte, R. S., \& Popuş, B. T. (2019). Assessment tasks to measure systems thinking and critical thinking in organic chemistry. Acta Chemica Iasi, 27(2), 251-262. https://doi.org/10.2478/achi2019-0016

Tune, J. D., Sturek, M., \& Basile, D. P. (2013). Flipped classroom model improves graduate student performance in cardiovascular, respiratory, and renal physiology. Advances in Physiology Education, 37(4), 316-320. https://doi.org/10.1152/advan.00091.2013

Wang, J. (2016). Research on application to college study in organic chemistry teaching based on computer software. MATEC Web of Conferences, 44, 01071. https://doi.org/10.1051/matecconf/20164401071

Xiong, Y. (2016). Research on the case teaching model of business administration specialty in undergraduate course. Proceedings of the 2016 3rd International Conference on Management, Education Technology and Sports Science (METSS 2016). https://doi.org/10.2991/metss16.2016 .92

Zhang, Yanqi, Zhou, L., Liu, X., Liu, L., Wu, Y., Zhao, Z., Yi, D., \& Yi, D. (2015). The effectiveness of the problem-based learning teaching model for use in introductory Chinese undergraduate medical courses: A systematic review and meta-analysis. PLOS ONE, 10(3), e0120884. https://doi.org/10.1371/journal.pone.0120884

Zhang, Yunshen. (2017). On study of teaching reform of organic chemistry course in applied chemical industry technology. IOP Conference Series: Earth and Environmental Science, 94(1), 012069. https://doi.org/10.1088/1755-1315/94/1/012069

Zheng, H., Hu, B., Sun, Q., Cao, J., \& Liu, F. (2020). Applying a chemical structure teaching method 
Jurnal Inovasi Pendidikan IPA, 6 (2), 2020 - 256

Wati Sukmawati

in the pharmaceutical analysis curriculum to improve student engagement and learning. Journal of Chemical Education, 97(2), 421-426. https://doi.org/10.1021/acs.jchemed.9b00551 